\title{
Selected aspects of environmentally oriented disassembly modeling of combustion engines
}

\begin{abstract}
The examinations of a product life cycle constitute a starting point in their design and improvement. The received results of environmental analysis carried out on a combustion engine showed both improving works on the problem of the selection of structural materials and the process of a disassembly of an end of life combustion engine. Generatign a model of this process allowed a constant optimization of the environment related recycling processes for which the basic process is a disassembly. The optimization of the disassembly process of an end of life combustion engine led to an increase in the level of the recovery and recycling from the vehicle. At the same time environmental benefits had a positive effect on the values of the economic indexes prepared for the recycling processes of end of life technological objects.
\end{abstract}

Key words: combustion engine, LCA, disassembly

\section{Wybrane aspekty prośrodowiskowego modelowania demontażu silników spalinowych}

Prowadzone badania cyklu życia obiektów technicznych stanowia punkt wyjścia podczas ich projektowania i doskonalenia. Otrzymane wyniki przeprowadzonej analizy ekobilansowej silnika spalinowego wskazały, że celowe jest prowadzenie i doskonalenie prac nad zagadnieniem doboru materiałów konstrukcyjnych i procesu demontażu silnika spalinowego wycofanego z eksploatacji. Zamodelowanie tego procesu pozwolito na ciagłe optymalizowanie pod względem środowiskowym procesów recyklingu, w których podstawa jest demontaż. Optymalizacja procesu demontażu silnika wycofanego z eksploatacji doprowadziła do wzrostu poziomu odzysku i recyklingu w odniesieniu do pojedynczego samochodu wycofanego z eksploatacji. Jednocześnie korzyści środowiskowe pozytywnie wptynęty na wzrost wskaźnika ekonomicznego przeprowadzonego procesu zagospodarowywania wycofanych z eksploatacji obiektów technicznych.

Słowa kluczowe: silnik spalinowy, LCA, demontaż

\section{Introduction}

Technological objects such as combustion engines are commonly seen as a basic source of pollution released to the environment. The attempts to improve such a perception were limited to the reduction of the emissions from this source. The reason for environment degradation caused by combustion engines are, however, more complex. They are not limited to the consequences of the combustion process but they are also related to the production processes and the use of natural resources in the production of combustion engines. The period of engine use itself with the noise emission, repairs and change of consumables adds to the degradation of the environment. The last stage of the engine life cycle i.e. its withdrawal from operation has a significant influence on the degradation of the natural environment. An appropriate recycling of the end of life engines may significantly reduce their adverse effects on the environment. Taking all the above aspects into account requires the application of an extended life cycle, that includes the influence of the technological objects such as combustion engines on the natural environment through the individual stages of their existence i.e. design, production, operation, recycling. Only such a complex approach to the existence of combustion engines leads to a reduction of the environmental impact generated by combustion engines.

\section{Wprowadzenie}

Obiekty techniczne w postaci silników spalinowych są powszechnie postrzegane jako podstawowe źródło zanieczyszczeń emitowanych do środowiska. Poprawa ich wizerunku ograniczała się jedynie do zmniejszenia ilości emitowanych spalin do środowiska. Natomiast przyczyny degradacji środowiska wywołane funkcjonowaniem silników spalinowych są jednak bardziej złożone. Nie ograniczają się one tylko do konsekwencji procesu spalania, ale wiążą się również z wykorzystaniem $\mathrm{w}$ procesie produkcji silników zasobów naturalnych i procesów wytwórczych, które także oddziałują na środowisko. Również proces eksploatacji silników spalinowych, podczas którego emitowany jest hałas, dokonywane są naprawy i wymiany płynów eksploatacyjnych, przyczynia się do degradacji środowiska. Ostatni etap cyklu życia silnika, czyli jego wycofanie z eksploatacji ma istotny wpływ na degradację środowiska naturalnego. Poprawne przeprowadzenie procesu zagospodarowania silników wycofanych z eksploatacji w znaczący sposób może zmniejszyć jego zły wpływ na środowisko. Uwzględnienie wszystkich tych aspektów wymaga stosowania rozszerzonego cyklu życia, który uwzględnia wpływ obiektów technicznych, jakimi są silniki spalinowe, na środowisko poprzez poszczególne fazy istnienia tego obiektu, tj. projektowanie, wytwarzanie, eksploatację i wycofanie z eksploatacji. Tylko takie kompleksowe podejście do silników spalinowych prowadzi do 


\section{LCA method}

For the evaluation of the environmental impact related to all the stages of a life cycle of a technological object such as a combustion engine we can use the life cycle assessment method (LCA). The LCA method, even though it is not the only technique of environmental management has a multitude of positive features [1]:

1) It includes the whole life cycle of a product: „from birth till death" - no stage in the life cycle is omitted,

2) It considers all the ecosystems and their elements which enables a full assessment of the product impact on the environment,

3) On one hand it normalizes data related to the amounts of materials and energy and on the other hand it normalizes pollution (emission to the atmosphere, water soil) and waste within individual functional units,

4) It has become a basis and a universal technique for the assessment of the influence of products, processes or services on the environment.

\section{Environmental analysis of a combustion engine}

The basic aim of the environmental analysis of a combustion engine is its assessment in terms of its environmental optimization particularly with respect to the environmental consequences of the engine recycling as the last stage of the life cycle of a technological object. The environmental analysis has been performed according to the assumptions of the LCA method and the results have been expressed in environmental points $(\mathrm{Pt})$. Positive values of the environmental points denote a negative impact on the environment and the negative values denotes environmental benefits.

Four combustion engines with their subassemblies have undergone an environmental analysis:

- SSM engine capacity $796 \mathrm{ccm}$

- SSP engine capacity $1398 \mathrm{ccm}$

- SSL engine capacity $1598 \mathrm{ccm}$

- SSN engine capacity $1998 \mathrm{ccm}$.

In order to depict the environmental analysis we performed an analysis of the SSL engine. The first stage of this analysis was the determination of the level of influence of the engine production process on the environment. Individual quantities of the interactions of the production process on the environment, divided into three categories, have been shown in Fig. 1.

For further analysis of the SSL engine environmental interactions a group of components GE has been selected. zmniejszenia i ograniczenia oddziaływań środowiskowych generowanych przez silniki spalinowe.

\section{Metoda LCA}

Do oceny oddziaływań środowiskowych związanych z wszystkimi fazami cyklu życia obiektu technicznego jakim jest silnik spalinowy można wykorzystać metodę oceny cyklu życia LCA (life cycle assessment). Metoda LCA, pomimo iż nie jest jedyną techniką zarządzania środowiskowego, ma wiele charakterystycznych cech, które decydują o jej zaletach. Do tych cech można zaliczyć [1]:

1) obejmuje cały cykl życia wyrobu: ,od narodzin do śmierci”, przez co nie zostaje pominięty żaden etap istnienia wyrobu,

2) uwzględnia wszystkie ekosystemy i ich elementy, dzięki czemu możliwa jest pełna ocena wpływu wyrobu na środowisko,

3) normalizuje z jednej strony dane dotyczące ilości wprowadzanych materiałów i energii, a z drugiej - powstanie zanieczyszczeń (emisja do powietrza, wody i gleby) oraz odpadów w ramach poszczególnych jednostek funkcjonalnych,

4) stała się podstawową i uniwersalną techniką oceny wpływu wyrobów, procesów lub usług na środowisko.

\section{Analiza środowiskowa silnika spalinowego}

Podstawowym celem analizy środowiskowej silnika spalinowego jest jego ocena pod kątem ewentualnej optymalizacji środowiskowej, ze szczególnym uwzględnieniem konsekwencji środowiskowych procesu zagospodarowywania wycofanych z eksploatacji silników, jako ostatniego etapu cyklu życia obiektów technicznych. Analizę środowiskową przeprowadzono zgodnie z założeniami metody LCA, a wyniki analizy wyrażono w punktach środowiskowych $(\mathrm{Pt})$. Dodatnie wartości punktów środowiskowych określają negatywny wpływ na środowisko, natomiast wartości ujemne oznaczają korzyści środowiskowe.

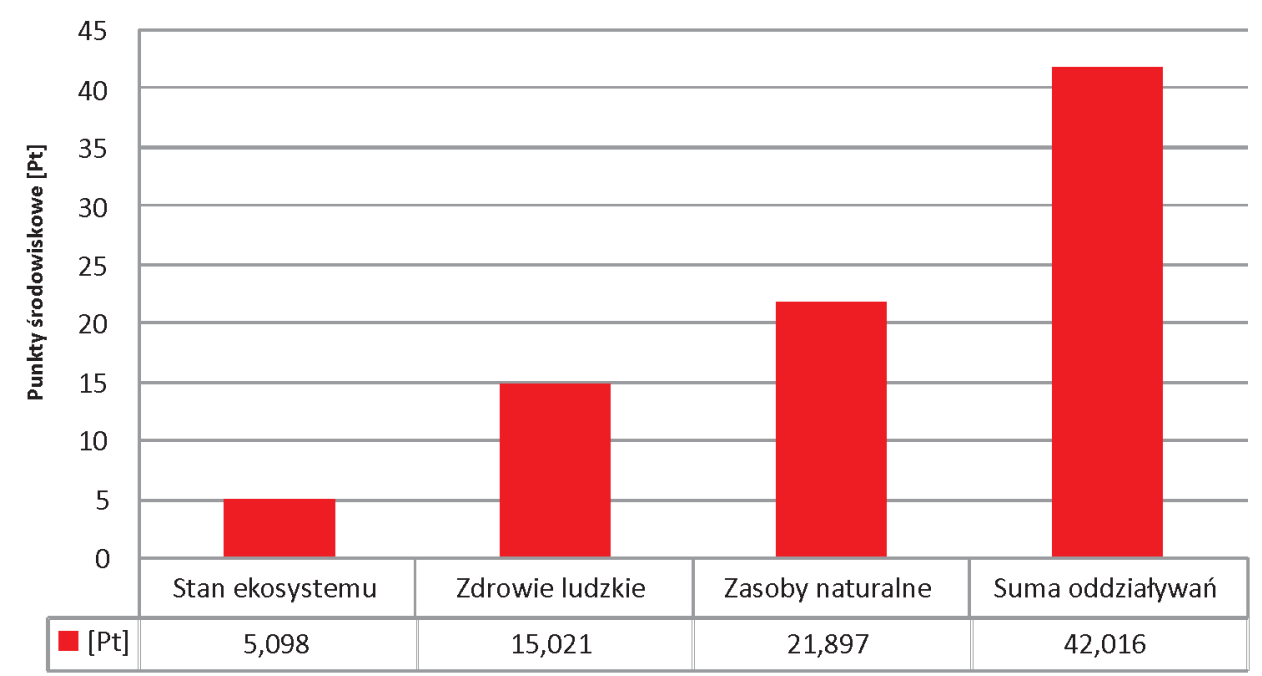

Fig. 1. Environmental influence of an SSL engine production taking into account the three categories of interactions Rys. 1. Środowiskowy wplyw procesu wytworzenia silnika SSL z uwzględnieniem trzech kategorii oddziaływań 
To this group the following components have been assigned: cylinder head, engine block, pistons, crankshaft, flywheel, starter motor, alternator, wire harnesses, oil pump, coolant pump. The production of the elements of this group generates an interaction of $29.431 \mathrm{Pt}$, which constitutes $75 \%$ of the total interactions on the environment related to the production of the whole SSL engine. The comparison of the above relations has been shown in Fig. 2.

The influence of individual raw materials on the environment also takes place at the stage of engine waste management when end of life. Such a generated waste must be recycled safely for the people and in an environment friendly way. Such a waste management should mean a maximum use of the components and consumables that come from that particular engine, very limited use in the energy recovery and an occasional disposal at a disposal site. In relation to waste management we may divide it into recycling and neutralization.

The process of neutralization consists in a safe management of the waste that cannot be reused. The waste undergoes a process of biological, physical and chemical transformations in order to ensure a condition when it does not pose any threat for the people and the environment. In the case of used up engines the process of neutralization does not take place as the produced waste can be reused or processed. The process that takes place here is the process of recovery.

Recovery as per the definition contained in the Waste Management Act, determines all the actions that are safe for the people and the environment leading to a use of the waste in part or as a whole or the recovery of the substances materials or energy from that waste [2]. According to this definition the recovery can be divided into two basic forms, i.e. recycling and energy recovery (Fig. 3).

The comparative analysis of recovery and waste disposal at the disposal site in relation to the end of life SSL engine shows that the process of recovery leads to certain environmental benefits and the disposal has a negative impact on the environment. The obtained results during disposal and recovery divided into individual groups have been shown in Fig. 4.

The largest environmental benefits on the level of $-14.182 \mathrm{Pt}$ and $-12.948 \mathrm{Pt}$ have been obtained after recovery of non ferrous and ferrous junk metals. The recovery of the outstanding materials led to environmental benefits of -0.781 Pt. The recovery of individual materials from an end of life engine is a source of environmental benefits on the level of $-27.948 \mathrm{Pt}$, while disposal of these materials has a negative impact on the environment on the level of $0.898 \mathrm{Pt}$.

A prerequisite for obtaining such large environmental benefits is a proper realization of the recovery process of the end of life engines and such a proper realization of this process requires a process of disassembly.

Disassembly means that a given product or its subassemblies is disintegrated to pieces and its purpose may be a replacement of a faulty component or a recovery of valuable components and materials from elements assigned for recycling or a retrieval of environmentally dangerous materials [3].
Analizie środowiskowej poddano cztery silniki spalinowe z osprzętem, oznaczone:

- SSM jednostka o pojemności $796 \mathrm{ccm}$

- SSP jednostka o pojemności $1398 \mathrm{ccm}$

- SSL jednostka o pojemności $1598 \mathrm{ccm}$

- SSN jednostka o pojemności $1998 \mathrm{ccm}$.

W celu zobrazowania analizy środowiskowej przeprowadzimy analizę jednostki SSL. Pierwszym etapem analizy środowiskowej było wyznaczenie poziomu wpływu na środowisko procesu wytworzenia tego silnika. Poszczególne wielkości oddziaływań procesu produkcyjnego na środowisko, z podziałem na trzy kategorie, przedstawiono na rys. 1.

Do dalszej analizy oddziaływań na środowisko z silnika SSL wybrano grupę elementów oznaczoną GE. Do grupy tej przypisano następujące elementy: głowica, blok silnika, tłoki, wał korbowy, koło zamachowe, rozrusznik, alternator, wiązkę przewodów elektrycznych, pompę oleju, pompę wody. Wytworzenie elementów tej grupy generuje oddziaływanie wysokości 29,431 Pt, co stanowi 75\% sumy oddziaływań na środowisko związanej z wytworzeniem całej jednostki SSL. Porównanie ww. zależności przedstawiono na rys. 2.

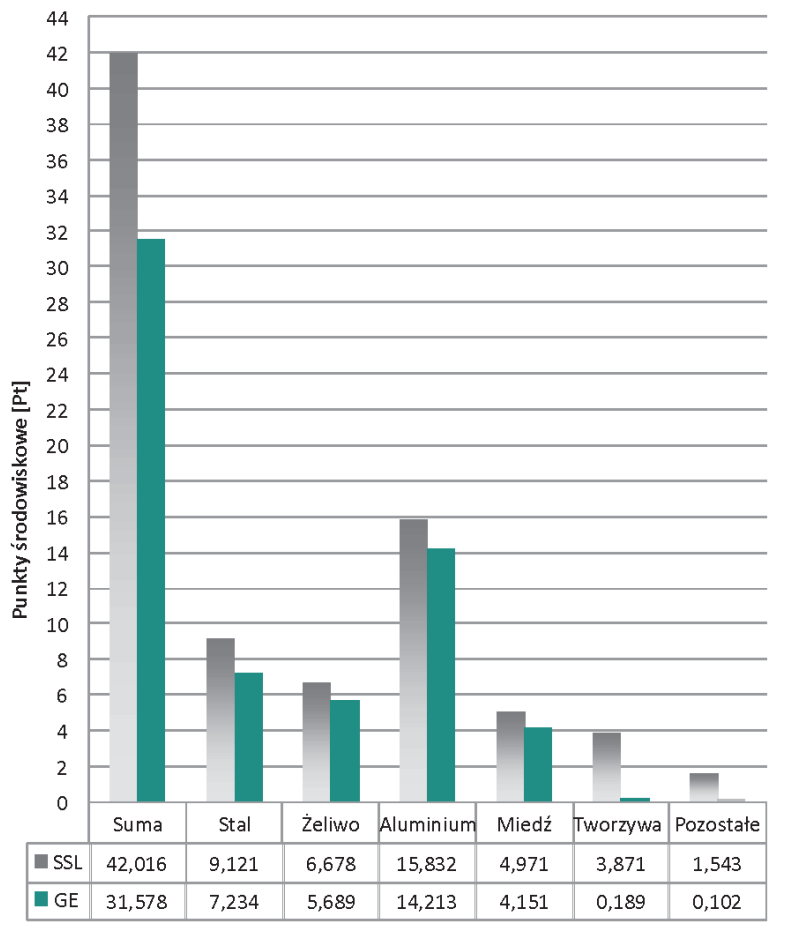

Fig. 2. Interactions of materials used in the group components GE with regard to generated burdens on the background of total results

Rys. 2. Oddziaływanie materiałów użytych w grupie elementów GE pod względem generowanych obciązeń na tle danych sumarycznych

Wpływ poszczególnych materiałów na środowisko występuje również na etapie zagospodarowywania silnika wycofanego z eksploatacji. Powstały odpad, w postaci silnika wycofanego z eksploatacji, należy zagospodarować w sposób bezpieczny i przyjazny dla życia i zdrowia ludzi oraz 


\section{Disassembly modeling}

In the here considerations it was assumed that in order to achieve an environmental goal i.e. recovery of components and materials from an end of life engine the process of disassembly is necessary that consists in specifically described disassembly operations of individual elements from that engine.

The structure of the process of the engine disassembly we will present through a graph where each operation is reflected in a graph link (arch). The components to be recovered and those already recovered are reflected as vertexes of this graph. The notation of this graph is as follows [4-6]:

$$
\mathrm{G}=\langle\mathrm{W}, \mathrm{O}, \mathrm{R}\rangle
$$

where: W - set of graph vertexes (components) G, O - set of graph links (disassembly operations) G, R - three-link relation, construed as a subset of the Cartesian product $\mathrm{W} \times \mathrm{O} \times \mathrm{W}$.

In order to avoid ambiguity of further considerations we will assume the following notation of the vertexes and links in graph $\mathrm{G}$ :

$$
\begin{gathered}
W=\{w(i) \equiv i: \quad i=1,2, \ldots, I\} \quad i=\{1,2, \ldots, i, j, \ldots, I\} \\
O=\{(w(i), w(j)): w(i), w(j) \in W, w(i) \neq w(j) i, j \in I\}
\end{gathered}
$$

from the above it results that the disassembly process under consideration has I graph vertexes and $\mathrm{K}$ graph links.

The $\mathrm{R}$ representation is performed by the Cartesian product $\mathrm{W} \times \mathrm{O} \times \mathrm{W}$ on the set $\{0,1\}[5]$ :

$$
\mathrm{R}: \mathrm{W} \times \mathrm{O} \times \mathrm{W} \rightarrow\{0,1\}
$$

A randomly selected ternary $(\mathrm{w}(\mathrm{i}), \mathrm{o}(\mathrm{k}), \mathrm{w}(\mathrm{j})) \in \mathrm{W} \times \mathrm{O} \times \mathrm{W}$, so that $\mathrm{R}(\mathrm{w}(\mathrm{i}), \mathrm{o}(\mathrm{k}), \mathrm{w}(\mathrm{j}))=1$ we interpret as follows: arch $\mathrm{o}(\mathrm{k})$ joining vertex $w(\mathrm{i})$ with vertex $\mathrm{w}(\mathrm{j}), \mathrm{w}(\mathrm{i}) \neq \mathrm{w}(\mathrm{j})$ or arch $\mathrm{o}(\mathrm{k})$ falls between vertexes $w(\mathrm{i})$ and $\mathrm{w}(\mathrm{j})$. A randomly selected ternary $(\mathrm{w}(\mathrm{i}), \mathrm{o}(\mathrm{k}), \mathrm{w}(\mathrm{j})) \in \mathrm{W} \times \mathrm{O} \times \mathrm{W}$ so that $\mathrm{R}(\mathrm{w}(\mathrm{i})$, $\mathrm{o}(\mathrm{k}), \mathrm{w}(\mathrm{j}))=0$ we interpret as follows: $\operatorname{arch} \mathrm{o}(\mathrm{k})$ does not join vertex w(i) with vertex $w(j), w(i) \neq w(j)$ or arch $o(k)$ does not fall between vertexes w(i) and(j).

In the engine disassembly process we require an order of the performed operations resulting from the design of this engine and the assumed technique of its disassembly. That is why for the description of this feature we use a directed graph being asymmetric and acyclic in the sense of $[4,5]$.

In the realization of the component and material recovery from an end of life engine we need to define the quantitative characteristics for the elements of the structure of the disassembly process. That is why the recovery of the components and materials for an engine we define a s an ordered ternary [4-6]:

$$
\mathrm{S}=\left\langle\mathrm{G}, \mathrm{F}_{\mathrm{W}}, \mathrm{F}_{\mathrm{O}}\right\rangle
$$

where: $\mathrm{G}$ - graph representing the structure of the disassembly process of an end of life vehicle, FW - a set of functions determined on the set of vertexes of graph $\mathrm{G}$. środowiska naturalnego. Zagospodarowanie to ma polegać na maksymalnym wykorzystaniu pochodzących z tego silnika elementów i materiałów w eksploatacji i przemyśle, bardzo ograniczonym wykorzystaniu w energetyce oraz sporadycznym składowaniu pozostałości na składowisku odpadów. W odniesieniu do odpadów mamy do czynienia z odzyskiem oraz z unieszkodliwianiem.

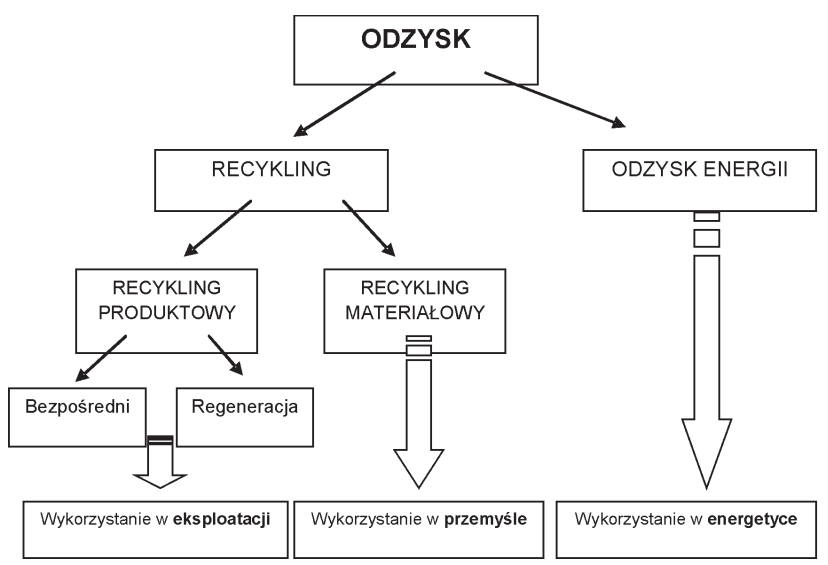

Fig. 3. Ways of recovery

Rys. 3. Formy odzysku

Proces unieszkodliwienia polega na bezpiecznym dla środowiska zagospodarowaniu odpadów, których nie można ponownie wykorzystać. Odpady są poddawane procesom przekształceń biologicznych, fizycznych lub chemicznych, w celu doprowadzenia ich do stanu, w którym nie stwarzają zagrożenia dla życia, zdrowia ludzi lub środowiska. W przypadku wyeksploatowanych silników proces unieszkodliwiania nie znajduje zastosowania, ponieważ wygenerowane odpady można ponownie wykorzystać lub przetworzyć. Znajduje natomiast zastosowanie proces odzysku.

Odzysk, zgodnie z definicją zawartą w ustawie o odpadach, określa wszelkie działania niestwarzające zagrożenia dla życia, zdrowia ludzi lub dla środowiska, prowadzące do wykorzystania odpadów w całości lub w części, albo do odzyskania z odpadów substancji, materiałów bądź energii i ich wykorzystania [2]. Zgodnie z tą definicją odzysk można podzielić na dwie podstawowe formy, tj. recykling i odzysk energii (rys. 3).

Analiza porównawcza odzysku i składowania odpadów na składowisku odpadów w odniesieniu do wycofanego z eksploatacji silnika SSL pokazuje, że proces odzysku prowadzi do uzyskania korzyści środowiskowych, a składowanie wpływa negatywnie na środowisko. Uzyskane wyniki podczas odzysku i składowania z podziałem na poszczególne grupy materiałowe przedstawiono na rys. 4.

Największe korzyści środowiskowe na poziomie -14,182 Pt i -12,948 Pt uzyskano po przeprowadzeniu procesu odzysku złomu metali nieżelaznych i żelaznych. Natomiast odzysk pozostałych materiałów doprowadził do uzyskania korzyści środowiskowych na poziomie $-0,781 \mathrm{Pt}$. Odzyskanie poszczególnych materiałów z silnika wycofanego z eksploatacji jest źródłem korzyści środowiskowych na pozio- 


$$
\mathrm{F}_{\mathrm{W}}=\left\{\varphi_{1}, \varphi_{2}, \ldots, \varphi_{\mathrm{u}}\right\} \quad \mathrm{u}=1,2, \ldots, \mathrm{U}
$$

$\mathrm{U}$-number of representations determined on the set of graph vertexes $\mathrm{G}, \mathrm{FO}$ - a set of functions determined on the set of graph $\mathrm{G}$ links.

$$
\mathrm{F}_{\mathrm{O}}=\left\{\gamma_{1}, \gamma_{2}, \ldots, \gamma_{\mathrm{z}}\right\} \quad \mathrm{z}=1,2, \ldots, \mathrm{Z}
$$

$\mathrm{Z}$ - number of representations determined on the set of graph G links.

In the component and material recovery under consideration graph $\mathrm{G}$ is a bipartite and complete one which means that the set of vertexes $\mathrm{W}$ can be divided into two disjoint subsets: set of components to be recovered EO and set of components and materials recovered OEM. We assume that:

$$
\begin{aligned}
& \mathrm{W}=\mathrm{EO} \cup \mathrm{OEM} \\
& \mathrm{EO} \cup \mathrm{OEM}=\varnothing
\end{aligned}
$$

For the clarity of the notation, let $\mathrm{A}, \mathrm{A} \subset \mathrm{W}$ denote a set of components to be recovered $\mathrm{EO}$, and $\mathrm{B}, \mathrm{B} \subset \mathrm{W}$ denote a set of recovered components and materials OEM. At the same time we assume that there are A elements to be recovered numbered $\mathrm{a}=1,2, \ldots, \mathrm{A}$ and $\mathrm{B}$ elements and materials recovered numbered $\mathrm{b}=1,2, \ldots, \mathrm{B}$. The relations between the ordered pair of vertexes of sets $A$ and $B$, however, is the relation of the recovery $\mathrm{A} \times \mathrm{B}$. The set of all the relations of the recovery $\mathrm{RD}$ we express as:

$$
\mathrm{RD} \subset(\mathrm{A} \times \mathrm{B})=\{(\mathrm{a}, \mathrm{b}): \mathrm{a} \in \mathrm{A}, \mathrm{b} \in \mathrm{B}\}
$$

The relation of recovery makes sense only if the vertex of the end of the relation of recovery is reachable from the vertex of the beginning of the relation of recovery, i.e. between vertexes $(a, a \in A)$ and $b \in B, a \neq b$ ) we can perform at least one operation of the disassembly process and such a relation of recovery is admissible.

Let us assume that between a randomly selected element $\mathrm{a}$ and a randomly selected element $\mathrm{b}$ i.e. any relation of recovery $(a, b) \in R D$, we can perform exactly one disassembly operation.

The components recovered from the end of life engine, taking the criterion of their possible reuse into account, were divided into two groups:

- the first are the components that are to be reused and remanufactured

- the second are the components, in which a significant criterion is the type of material from which they were manufactured.

For the description of the said groups we can apply a model of the structure of the recovered components and materials as follows:

$$
\mathrm{OEM}_{\mathrm{d}}=(\mathrm{OE}, \mathrm{OM})
$$

where: OEM - recovered components and materials from the end of life engine, $\mathrm{d}$ - identification number of the end of life engine, $\mathrm{OE}$ - set of recovered components from the end of life engine, $\mathrm{OM}$ - set of recovered materials from the end of life engine. mie $-27,948 \mathrm{Pt}$, podczas gdy składowanie tych materiałów jako odpadów na składowisku odpadów wywiera negatywny wpływ na środowisko na poziomie $0,898 \mathrm{Pt}$.

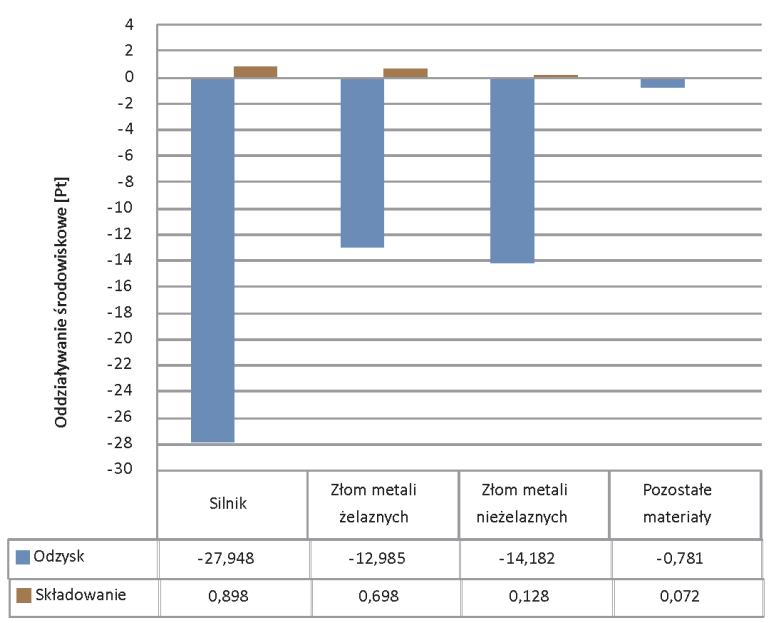

Fig. 4. Levels of interactions generated during recovery and disposal Rys. 4. Poziomy oddziaływań generowanych podczas odzysku i składowaniu odpadów

Warunkiem koniecznym uzyskania tak dużych korzyści środowiskowych jest poprawne przeprowadzenie procesu odzysku elementów i materiałów z silników wycofanych z eksploatacji, natomiast prawidłowe przeprowadzenie odzysku wymaga zastosowania procesu demontażu.

Demontaż określany jest jako proces rozłożenia wyrobu na pojedyncze elementy lub podzespoły, a celem może być wymiana uszkodzonego elementu, odzyskanie wartościowych elementów i materiałów z wyrobów przeznaczonych do recyklingu lub wydobycie z nich materiałów szkodliwych dla środowiska [3].

\section{Modelowanie demontażu}

W prowadzonych rozważaniach założono, że do osiągnięcia zamierzonego celu środowiskowego, tj. odzysku elementów i materiałów z silnika wycofanego z eksploatacji, niezbędny jest proces demontażu, który składa się z dokładnie określonych operacji demontażu poszczególnych elementów z silnika wycofanego z eksploatacji.

Strukturę procesu demontażu silnika wycofanego z eksploatacji będziemy przedstawiać za pomocą grafu, w którym każda operacja demontażowa jest odwzorowana w postaci połączenia (łuku) grafu. Natomiast elementy do odzyskania i odzyskane odwzorowane są w postaci wierzchołków tego grafu. Graf ten zapisuje się w postaci (1) [4-6]: gdzie: W - zbiór wierzchołków (elementów) grafu $\mathrm{G}, \mathrm{O}$ - zbiór połączeń (operacji demontażowych) grafu $\mathrm{G}$, $\mathrm{R}$ - relacja trójczłonowa, rozumiana jako podzbiór iloczynu kartezjańskiego $\mathrm{W} \times \mathrm{O} \times \mathrm{W}$.

Dla jednoznaczności prowadzenia dalszych rozważań przyjmujemy notację (2) i (3) wierzchołków i połączeń w grafie $\mathrm{G}$.

Z powyższego wynika, że rozpatrywany proces demontażu ma I wierzchołków grafu oraz K połączeń grafu. 
The structure of the set of recovered components from the end of life engine we will define as a sum of the set of recovered components for reuse and the set of recovered components for remanufacturing:

$$
\mathrm{OE}=\mathrm{OEP} \cup \mathrm{OER}
$$

where: OE - set of recovered components from the end of life engine, OEP - set of recovered components for reuse, OER - set of recovered components for remanufacturing.

The structure of the set of recovered materials we will define as a sum of sets of recovered consumable fluids fuels and materials:

$$
\mathrm{OM}=\mathrm{OMP} \cup \mathrm{OMS}
$$

where: $\mathrm{OM}$ - the set of recovered materials from the end of life engine, OMP - set of recovered consumable fluids and fuels, OMS - set of recovered materials.

The set of recovered materials is:

$$
\mathrm{OMS}=\mathrm{OZ} \cup \mathrm{OPM}
$$

$\mathrm{OZ}$ - set of recovered metal junk

$$
\mathrm{OZ}=\mathrm{OZS} \cup \mathrm{OZK} \cup \mathrm{OZMS}
$$

$\mathrm{OZS}$ - set of recovered ferrous metal junk,

$$
\mathrm{OZS}=\left\{\mathrm{OZS}_{1}, \mathrm{OZS}_{2}, \mathrm{ozS}_{3}, \mathrm{ozS}_{4}\right\}
$$

where: ozs $_{1}$ - junk metal of thickness larger than $4 \mathrm{~mm}$, $\mathrm{Ozs}_{2}$ - junk metal of thickness up to $4 \mathrm{~mm}, \mathrm{ozs}_{3}-$ mixed junk metal, ozs s $_{4}$ junk for scrapping, $\mathrm{OZK}$ - set of recovered non-ferrous metal junk,

$$
\mathrm{OZK}=\left\{\mathrm{ozk}_{1}, \mathrm{ozk}_{2}, \mathrm{ozk}_{3}, \mathrm{ozk}_{4}\right\}
$$

where: ozk1 - aluminum and aluminum alloy junk, ozk2 - copper and copper alloy junk, ozk3 - zinc and zinc alloy junk, ozk4 - other non-ferrous metal junk, OZMS - set of recovered noble metal junk, OPM - set of other recovered materials,

$$
\mathrm{OPM}=\mathrm{OTS} \cup \mathrm{OG} \cup \mathrm{OPO}
$$

OTS - set of recovered plastic materials,

$$
\text { OTS }=\left\{\text { ots }_{1}, \text { ots }_{2}, \ldots, \text { ots }_{6}\right\}
$$

where: ots ${ }_{1}-$ recovered single component plastics, ots ${ }_{2}$ recovered plastic alloys, ots ${ }_{3}-$ recovered modified plastics, ots $_{4}-$ recovered plastics with fillers and hardeners, ots ${ }_{5}$ recovered rubber, ots ${ }_{6}$ - recovered mixed plastics,

$\mathrm{OG}-$ set of recovered rubber material,

$\mathrm{OPO}$ - set of recovered other waste.

\section{The parameters and criteria of recovery}

\section{Recovered mass}

Each relation of recovery is characterized by a quantity construed as a demand for a component to be recovered in a given relation. We assume that on the set of relation of recovery $\mathrm{RO}$ there is representation $\mathrm{m}$ :
Natomiast odwzorowanie R przeprowadza iloczyn kartezjański $\mathrm{W} \times \mathrm{O} \times \mathrm{W}$ na zbiór $\{0,1\}$ (4) [5].

Dowolną trójkę (w(i), o(k), w(j)) $\in \mathrm{W} \times \mathrm{O} \times \mathrm{W}$ taką, że $\mathrm{R}(\mathrm{w}(\mathrm{i}), \mathrm{o}(\mathrm{k}), \mathrm{w}(\mathrm{j}))=1$ interpretujemy w sposób następujący: łuk o(k) łączący wierzchołek w(i) z wierzchołkiem w(j), $\mathrm{w}(\mathrm{i}) \neq \mathrm{w}(\mathrm{j})$ lub łuk o(k) jest zawarty między wierzchołkami w(i) oraz w(j). Natomiast dowolną trójkę (w(i), o(k), w(j)) $\in \mathrm{W} \times \mathrm{O} \times \mathrm{W}$ taką, że $\mathrm{R}(\mathrm{w}(\mathrm{i}), \mathrm{o}(\mathrm{k}), \mathrm{w}(\mathrm{j}))=0$ interpretujemy następująco: łuk o(k) nie łączy wierzchołka w(i) z wierzchołkiem w(j), w(i) $\neq w(j)$ lub łuk o(k) nie jest zawarty między wierzchołkami w(i) oraz w(j).

W procesie demontowania silnika wymagana jest odpowiednia kolejność wykonania operacji, wynikająca z konstrukcji tego silnika i przyjętej technologii jego demontażu. Dlatego do opisu tej cechy wykorzystywany jest graf skierowany, mający właściwość asymetryczności oraz acykliczności w sensie dróg [4, 5].

W realizacji odzysku elementów i materiałów z silnika wycofanego z eksploatacji zachodzi potrzeba definiowania charakterystyk ilościowych dla elementów struktury procesu demontażu. Dlatego odzysk elementów i materiałów z silnika wycofanego z eksploatacji definiujemy jako trójkę uporządkowaną [4-6] - wzór (5), gdzie: G - graf odwzorowujący strukturę procesu demontażu samochodu wycofanego $\mathrm{z}$ eksploatacji, $\mathrm{F}_{\mathrm{W}}$ - zbiór funkcji określonych na zbiorze wierzchołków grafu G (6), gdzie: U - liczba odwzorowań określonych na zbiorze wierzchołkach grafu $\mathrm{G}$, $\mathrm{F}_{\mathrm{O}}$ - zbiór funkcji określonych na zbiorze połączeń grafu $\mathrm{G}$ (7), gdzie: Z - liczba odwzorowań określonych na zbiorze połączeń grafu $\mathrm{G}$.

W rozpatrywanym odzysku elementów i materiałów $\mathrm{z}$ silnika wycofanego z eksploatacji graf G jest grafem dwudzielnym i pełnym, co oznacza, że zbiór wierzchołków W można podzielić na dwa rozłączne podzbiory: na zbiór elementów do odzyskania EO i zbiór odzyskanych elementów i materiałów OEM - wzory (8) i (9).

Dla przejrzystości zapisu niech $\mathrm{A}, \mathrm{A} \subset \mathrm{W}$ oznacza zbiór elementy do odzyskania $\mathrm{EO}, \mathrm{a} \mathrm{B}, \mathrm{B} \subset \mathrm{W}$ oznacza zbiór odzyskane elementy i materiały OEM. Równocześnie przyjmujemy, że istnieje A elementów do odzyskania ponumerowanych $\mathrm{a}=1,2, \ldots, \mathrm{A}$ i B elementów i materiałów odzyskanych ponumerowanych $\mathrm{b}=1,2, \ldots, \mathrm{B}$. Natomiast związek pomiędzy uporządkowaną parą wierzchołków zbiorów A i B stanowi relację odzysku $\mathrm{A} \times \mathrm{B}$. Zbiór wszystkich relacji odzysku RD określamy jako (10).

Relacja odzysku ma sens tylko wtedy, gdy wierzchołek końca relacji odzysku jest osiągalny z wierzchołka początku relacji odzysku, czyli między wierzchołkami (a, a $\in \mathrm{A})$ oraz $(\mathrm{b}, \mathrm{b} \in \mathrm{B}, \mathrm{a} \neq \mathrm{b}$ ) można przeprowadzić co najmniej jedną operację procesu demontażu i dopuszczalna jest taka relacja odzysku. Przyjmujemy, że między dowolnym elementem a i dowolnym elementem b, czyli w dowolnej relacji odzysku $(\mathrm{a}, \mathrm{b}) \in \mathrm{RD}$, można przeprowadzić dokładnie jedną operację demontażową.

Odzyskane elementy z silnika wycofanego z eksploatacji, przy uwzględnieniu kryterium ich ponownego wykorzystania, podzielono na dwie grupy: 


$$
\mathrm{m}: \mathrm{RO} \rightarrow \mathrm{R}^{+}
$$

where $\mathrm{m}(\mathrm{a}, \mathrm{b}) \equiv \mathrm{m}^{(\mathrm{a}, \mathrm{b})}$ is a real non-negative number having expressing the demand for a component in the relation of recovery $(a, b)$.

We also assume that on the Cartesian product $\mathrm{O}^{\mathrm{ab}} \times \mathrm{W} \times \mathrm{W}$ we have a representation $\mathrm{m}$ :

$$
\mathrm{m}: \mathrm{O}^{\mathrm{ab}} \times \mathrm{W} \times \mathrm{W} \rightarrow \mathrm{R}^{+}
$$

where $\mathrm{O}^{\mathrm{ab}}$ - set of links joining the vertexes a and $\mathrm{b}, \mathrm{m}(\mathrm{a}$, b) - a real positive number expressing the recovered mass in the relation of recovery $(a, b)$. For clarity we will apply the following notation:

$$
\mathrm{m}(\mathrm{a}, \mathrm{b}) \equiv \mathrm{m}^{(\mathrm{a}, \mathrm{b})}
$$

The recovered mass has been limited in the following manner: the condition of non-nagativeness (the value of the recovered mass in any given relation of recovery cannot take a negative value), which is:

$$
\forall(a, b) \in R O, \quad\left(m^{(a, b)} \geq 0\right)
$$

\section{Disassembly time}

We assume that on the Cartesian product $\mathrm{O}^{\mathrm{ab}} \times \mathrm{W} \times \mathrm{W}$ we have a representation $\mathrm{td}$ :

$$
\mathrm{td}: \mathrm{O}^{\mathrm{ab}} \times \mathrm{W} \times \mathrm{W} \rightarrow \mathrm{R}^{+}
$$

where quantity $\operatorname{td}(a, b)$ is a real non-negative number expressing the disassembly time $(i, j)$, in the relation of recovery $(a, b)$. For clarity we will apply the following notation:

$$
\operatorname{td}((a, b),(i, j)) \equiv \operatorname{td}^{(a, b)}
$$

The disassembly time has been limited in the following manner: the condition of non-nagativeness (the disassembly time of any given disassembly operation $(i, j)$ cannot take a negative value), which is:

$$
\forall(\mathrm{a}, \mathrm{b}) \in \mathrm{RD}, \quad \forall(\mathrm{i}, \mathrm{j}) \in \mathrm{O} \quad\left(\operatorname{td}^{(\mathrm{a}, \mathrm{b})} \geq 0\right)
$$

If in a given relation of recovery $(a, b)$ a non-destructive disassembly takes place, we determine the non-destructive disassembly time.

We assume that on the Cartesian product $\mathrm{O}^{\mathrm{ab}} \times \mathrm{W} \times \mathrm{W}$ we have a representation tdn:

$$
\operatorname{tdn}: \mathrm{O}^{\mathrm{ab}} \times \mathrm{W} \times \mathrm{W} \rightarrow \mathrm{R}^{+}
$$

where quantity $\operatorname{tdn}((a, b),(i, j))$ is a real non-negative number expressing the non-destructive disassembly time of the disassembly operation $(i, j)$, in the relation of recovery (a, b). For clarity we will apply the following notation:

$$
\operatorname{tdn}((a, b),(i, j)) \equiv \operatorname{tdn}^{(a, b)}
$$

The non-destructive disassembly time has been limited in the following manner: the condition of non-nagativeness (the disassembly time of any given disassembly operation $(i, j)$ cannot take a negative value), which is:
- pierwszą tworzą elementy do ponownego użycia w eksploatacji i elementy do regeneracji

- drugą tworzą elementy, w których istotnym kryterium jest rodzaj materiału, z jakiego zostały wytworzone.

Do opisu wymienionych grup można zastosować model struktury odzyskanych elementów i materiałów z silnika wycofanego z eksploatacji określany jako (11), gdzie: OEM - odzyskane elementy i materiały z silnika wycofanego z eksploatacji, $\mathrm{d}$ - numer ewidencyjny silnika wycofanego z eksploatacji, OE - zbiór odzyskane elementy z silnika wycofanego z eksploatacji, OM - zbiór odzyskane materiały z silnika wycofanego z eksploatacji.

Strukturę zbioru odzyskane elementy z silnika wycofanego z eksploatacji będziemy definiować jako sumę zbioru odzyskane elementy do ponownego użycia w eksploatacji i zbioru odzyskane elementy do regeneracji (12), gdzie: OE - zbiór odzyskane elementy z silnika wycofanego z eksploatacji, OEP - zbiór odzyskane elementy do ponownego użycia w eksploatacji, OER - zbiór odzyskane elementy do regeneracji.

Strukturę zbioru odzyskane materiały będziemy definiować jako sumę zbiorów odzyskane płyny eksploatacyjne i paliwa oraz odzyskane materiały (13), gdzie: OM - zbiór odzyskane materiały z silnika wycofanego z eksploatacji, OMP - zbiór odzyskane płyny eksploatacyjne i paliwa, OMS - zbiór odzyskane materiały.

Zbiór odzyskane materiały określamy jako (14), gdzie: OZ - zbiór odzyskany złom metali (15), gdzie: OZS - zbiór

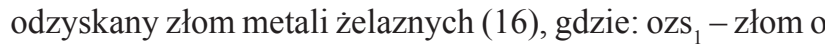
grubości powyżej $4 \mathrm{~mm}$, ozs $_{2}$ - złom o grubości do $4 \mathrm{~mm}$, $\mathrm{ozs}_{3}$ - złom mieszany, ozs ${ }_{4}$ - złom do strzępienia.

OZK - zbiór odzyskany złom metali nieżelaznych (17), gdzie: ozk $\mathrm{k}_{1}-\mathrm{złom} \mathrm{aluminium} \mathrm{i} \mathrm{stopy} \mathrm{aluminium,} \mathrm{ozk}_{2}-\mathrm{złom}$ miedzi i stopy miedzi, ozk - złom cynku i stopy cynku, $\mathrm{ozk}_{4}-$ złom innych metali nieżelaznych,

OZMS - zbiór odzyskany złom metali szlachetnych,

OPM - zbiór odzyskane pozostałe materiały (18),

OTS - zbiór odzyskane tworzywa sztuczne (19), gdzie: ots - odzyskane tworzywa jednoskładnikowe, ots ${ }_{2}$ - odzyskane stopy tworzyw, ots ${ }_{3}$ - odzyskane tworzywa zmodyfikowane, ots $_{4}$ - odzyskane tworzywa z wypełniaczami i materiałami utwardzającymi, ots ${ }_{5}$ - odzyskane kauczuki, ots ${ }_{6}$ - odzyskane tworzywa mieszane,

OG - zbiór odzyskany materiał gumowy, OPO - zbiór odzyskane pozostałe odpady.

\section{Parametry i kryteria oceny odzysku}

\section{Masa odzyskana}

Każdą relację odzysku charakteryzuje wielkość rozumiana jako zapotrzebowanie na element, który należy odzyskać w danej relacji. Zakładamy, że na zbiorze relacji odzysku RO zadane jest odwzorowanie $\mathrm{m}(20)$, gdzie $\mathrm{m}(\mathrm{a}, \mathrm{b}) \equiv \mathrm{m}^{(\mathrm{a}, \mathrm{b})}$ jest liczbą rzeczywistą nieujemną o interpretacji wielkości zapotrzebowania na element w relacji odzysku (a, b).

Przyjmujemy również, że na iloczynie kartezjańskim $\mathrm{O}^{\mathrm{ab}} \times \mathrm{W} \times \mathrm{W}$ zadane jest odwzorowanie $\mathrm{m}(21)$, gdzie $\mathrm{O}^{\mathrm{ab}}$ zbiór połączeń łączących wyróżnione wierzchołki a oraz 


$$
\forall(\mathrm{a}, \mathrm{b}) \in \mathrm{RD}, \quad \forall(\mathrm{i}, \mathrm{j}) \in \mathrm{O} \quad\left(\operatorname{tdn}^{(\mathrm{a}, \mathrm{b})} \geq 0\right)
$$

\section{The level of recovery}

Level of recovery PO is construed as a ratio of the sum of masses of the recovered components sent to be recycled from an end of life engine to the mass of the withdrawn engine:

$$
\mathrm{PO}_{\mathrm{d}}=\frac{\mathrm{MOE}+\mathrm{MMO}}{\mathrm{M}_{\text {swe }}} \times 100 \%
$$

where: PO - level of recovery from an end of life engine, $\mathrm{d}$ - engine identification number, MOE - mass of recovered components, $\mathrm{MMO}$ - mass of recovered components sent to be recovered, $\mathrm{M}_{\text {swe }}-$ mass of the end of life engine.

The mass of the recovered components from the end of life engine we construe as the sum of the masses of all the components from the set of recovered components from the end of life engine $\mathrm{OE}$ :

$$
\mathrm{MOE}_{\mathrm{d}}=\sum_{\mathrm{k}=1}^{\mathrm{m}} \mathrm{moe}_{\mathrm{k}}
$$

where: MOE - mass of the recovered components from the end of life engine, $\mathrm{d}$ - engine identification number, moe - mass of the component from the set of recovered components from the end of life engine $\mathrm{OE}, \mathrm{k}-$ index of the recovered component from the set $\mathrm{OE}, \mathrm{m}-$ number of recovered components $\mathrm{OE}$.

The mass of the recovered components from the end of life engine sent to be recycled is construed as a sum of the masses of the recycled recovered components from the end of life engine and the mass of the material fraction from the scrapping whose management is included in the process of recovery:

$$
\mathrm{MMO}_{\mathrm{d}}=\sum_{\mathrm{l}=1}^{\mathrm{n}} \mathrm{momo}_{1}+\mathrm{MFO}
$$

where: $\mathrm{MMO}$ - mass of the recovered materials from the end of life engine sent to be recycled, $\mathrm{d}$ - engine identification number, momo - mass of the recovered material from the set of recovered materials from the end of life engine, then recycled OMO, 1-index of the recovered material from set OMO, $\mathrm{n}$ - number of recovered materials from set OMO, MFO - mass of the material fraction from the scrapping whose management is included in the process of recovery:

$$
\mathrm{MFO}=\operatorname{mozs}_{4} \times\left(\frac{\mathrm{f}_{\mathrm{o} 1}+\mathrm{f}_{\mathrm{o} 2}+\mathrm{f}_{\mathrm{o3}}}{100}\right)
$$

where: mozs $_{4}$ - mass of scrap metal, fo ${ }_{1}$ - percentage share of the fraction of plastic, in case recycling is impossible (data from the scrapping trial), $\mathrm{fo}_{2}$ - percentage share of a light fraction and dust that do not contain dangerous substances in case energy recovery is possible (data from the scrapping trial), fo $_{3}$ - percentage share of a light fraction and dust that contain dangerous substances in case energy recovery is possible (data from the scrapping trial). b, $\mathrm{m}(\mathrm{a}, \mathrm{b})$ - liczba rzeczywista dodatnia o interpretacji wielkości masy odzyskanej w relacji odzysku (a, b). Dla przejrzystości zapisu będziemy stosować notację (22).

Na wielkość masy odzyskanej nałożono ograniczenie w postaci: warunek nieujemności (wartość masy odzyskanej w dowolnej relacji odzysku nie może mieć wartości ujemnej), co zapisujemy wzorem (23).

\section{Czas demontażu}

Przyjmujemy, że na iloczynie kartezjańskim $\mathrm{O}^{\mathrm{ab}} \times \mathrm{W} \times \mathrm{W}$ zadane jest odwzorowanie td (24), gdzie wielkość td(a, b) jest liczbą rzeczywistą nieujemną o interpretacji czasu demontażu operacji demontażowej (i,j), w relacji odzysku (a,b). Dla przejrzystości zapisu będziemy stosować notację (25).

Na wielkość czasu demontażu nałożono ograniczenie w postaci: warunek nieujemności (czas demontażu dowolnej operacji demontażowej $(i, j)$ nie może przyjmować wartości ujemnej), co zapisujemy (26).

Jeżeli w danej relacji odzysku (a, b) mamy do czynienia z operacją demontażu nieniszczącego, wyznaczamy czas demontażu nieniszczącego tdn.

Przyjmujemy, że na iloczynie kartezjańskim $\mathrm{O}^{\mathrm{ab}} \times \mathrm{W} \times \mathrm{W}$ zadane jest odwzorowanie tdn (27), gdzie wielkość tdn((a,b), $(i, j))$ jest liczbą rzeczywistą nieujemną o interpretacji czasu demontażu nieniszczącego operacji demontażowej (i, j), w relacji odzysku $(\mathrm{a}, \mathrm{b})$. Dla przejrzystości zapisu będziemy stosować notację (28).

Na wielkość czasu demontażu nieniszczącego nałożono ograniczenie: warunek nieujemności (czas demontażu nieniszczącego dowolnej operacji demontażowej (i,j) nie może przyjmować wartości ujemnej), co zapisujemy w postaci (29).

\section{Poziom odzysku}

Poziom odzysku PO jest określany jako stosunek sumy masy odzyskanych elementów z silnika wycofanego z eksploatacji i masy odzyskanych materiałów z silnika wycofanego z eksploatacji przekazanych do odzysku do masy silnika wycofanego z eksploatacji (30), gdzie: $\mathrm{PO}$ - poziom odzysku silnika wycofanego z eksploatacji, d - numer ewidencyjny silnika wycofanego z eksploatacji, MOE - masa odzyskanych elementów z silnika wycofanego z eksploatacji, MMO - masa odzyskanych materiałów z silnika wycofanego z eksploatacji przekazanych do odzysku, $\mathrm{M}_{\text {swe }}$ - masa silnika wycofanego z eksploatacji.

Masę odzyskanych elementów z silnika wycofanego z eksploatacji określamy jako sumę masy wszystkich elementów ze zbioru odzyskane elementy z silnika wycofanego z eksploatacji OE (31), gdzie: MOE - masa odzyskanych elementów z silnika wycofanego z eksploatacji, d - numer ewidencyjny silnika wycofanego z eksploatacji, moe - masa elementu ze zbioru odzyskane elementy z silnika wycofanego z eksploatacji OE, k - indeks odzyskanego elementu ze zbioru OE, $\mathrm{m}$ - liczba odzyskanych elementów zbioru OE.

Masa odzyskanych materiałów z silnika wycofanego z eksploatacji, przekazywanych do odzysku, określana jest jako suma masy odzyskanych materiałów z silnika wycofanego z eksploatacji poddawanych procesom odzysku i masy frakcji materiałowych pochodzących ze strzępienia, 


\section{Recycling level}

The level of recycling PR shall be construed as a ratio of the sum of the masses of the recovered components from the end of life engine and the mass of the recovered materials from the end of life engine, sent to be recycled to the mass of the engine:

$$
\mathrm{PR}_{\mathrm{d}}=\frac{\mathrm{MOE}+\mathrm{MMR}}{\mathrm{M}_{\text {swe }}} \times 100 \%
$$

where: PR - level of recycling, $\mathrm{d}$ - engine identification number, MOE - mass of the recovered components from the end of life engine, MMR - mass of the recovered materials from the end of life engine sent to be recycled, $\mathrm{M}_{\text {swe }}-$ mas of the end of life engine.

The mass of the recovered components from the end of life engine sent to be recycled is construed as the sum of the masses of the recovered materials from the end of life engine then recycled and the mass of the material fraction from the scrapping whose management is included in the process of recycling:

$$
\mathrm{MMR}_{\mathrm{d}}=\sum_{\mathrm{p}=1}^{\mathrm{q}} \mathrm{momr}_{\mathrm{p}}+\mathrm{MFR}
$$

where: MMR - mass of the recovered materials from the end of life engine sent to be recycled, $\mathrm{d}$ - engine identification number, momr - mass of the recovered material from the set of recovered materials from the end of life engine then recycled OMR, $\mathrm{p}$ - index of the recovered material from set OMR, $\mathrm{q}$ - number of the recovered materials from set OMR, MFR - mass of the material fraction from the scrapping whose management is included in the process of recycling:

$$
\text { MFR }=\text { mozs }_{4} \times\left(\frac{f_{r 1}+f_{r 2}+f_{r 3}}{100}\right)
$$

where: mozs $_{4}-$ mass of the junk metal for scrapping, $f_{r 1}$ - percentage share of the fractions of ferrous metals (data from the scrapping trial), $\mathrm{f}_{\mathrm{r} 2}$ - percentage share of the fractions of non-ferrous metals (data from the scrapping trial), $\mathrm{f}_{\mathrm{r} 3}$ - percentage share of the plastic fraction (data from the scrapping trial).

\section{The task of recovery of the components from the end of life engine}

From the analysis of the individual levels of interactions generated during the recovery and disposal of materials it results (Fig. 3) that the recovery of the junk non-ferrous metals will bring more benefits than it is in the case of ferrous metals whose mass in the engine under analysis constitutes more than $60 \%$ of the total mass of this unit. With such extensive environmental benefits it is recommended to attempt an optimization of the junk non-ferrous metal recovery from this type of engine. In the structure of the junk non-ferrous metals a dominant material is aluminum and its alloys.

The task consists in performing a recovery of aluminum from a SSM, SSP, SSL and SSN engines. Aluminum will be obtained from the disassembled components that were made których zagospodarowanie zalicza się do procesów odzysku - wzór (32), gdzie: MMO - masa odzyskanych materiałów z silnika wycofanego z eksploatacji przekazywanych do odzysku, d - numer ewidencyjny silnika wycofanego z eksploatacji, momo - masa odzyskanego materiału ze zbiór odzyskanych materiałów z silnika wycofanego z eksploatacji poddawanych procesom odzysku OMO, $1-$ indeks odzyskanego materiału ze zbioru OMO, n - liczba odzyskanych materiałów ze zbioru OMO, MFO - masa frakcji materiałowych pochodzących ze strzępienia, których zagospodarowanie zalicza się do procesów odzysku (33), gdzie: mozs $_{4}$ - masa złomu do strzępienia, fo ${ }_{1}$ - procentowy udział frakcji tworzywa sztucznego, w przypadku braku możliwości poddania jej procesom recyklingu (dane z próby strzępienia), fo $\mathrm{f}_{2}$ - procentowy udział lekkiej frakcji i pyłu niezawierające substancji niebezpiecznych, w przypadku możliwości poddania jej procesom odzysku energii (dane z próby strzępienia), fo f $_{3}$ procentowy udział lekkiej frakcji i pyłu zawierające substancje niebezpieczne, w przypadku możliwości poddania jej procesom odzysku energii (dane z próby strzępienia).

\section{Poziom recyklingu}

Poziom recyklingu PR będzie określany jako stosunek sumy masy odzyskanych elementów z silnika wycofanego z eksploatacji i masy odzyskanych materiałów z silnika wycofanego z eksploatacji, przekazywanych do recyklingu, do masy silnika wycofanego z eksploatacji (34), gdzie: PR - poziom recyklingu, $\mathrm{d}$ - numer ewidencyjny silnika wycofanego $\mathrm{z}$ eksploatacji, MOE - masa odzyskanych elementów z silnika wycofanego z eksploatacji, MMR - masa odzyskanych materiałów z silnika wycofanego z eksploatacji przekazywanych do recyklingu, $\mathrm{M}_{\text {swe }}$ - masa silnika wycofanego $\mathrm{z}$ eksploatacji.

Masa odzyskanych materiałów z silnika wycofanego z eksploatacji przekazywanych do recyklingu określana jest jako suma masy odzyskanych materiałów z silnika wycofanego $\mathrm{z}$ eksploatacji poddawanych procesom recyklingu i masy frakcji materiałowych pochodzących ze strzępienia, których zagospodarowanie zalicza się do procesów recyklingu (35), gdzie: MMR - masa odzyskanych materiałów z silnika wycofanego $\mathrm{z}$ eksploatacji przekazywanych do recyklingu, d - numer ewidencyjny silnika wycofanego z eksploatacji, momr - masa odzyskanego materiału ze zbiór odzyskanych materiałów z silnika wycofanego z eksploatacji poddawanych procesom recyklingu OMR, p indeks odzyskanego materiału ze zbioru OMR, q - liczba odzyskanych materiałów ze zbioru OMR, MFR - masa frakcji materiałowych pochodzących ze strzępienia, których zagospodarowanie zalicza się do procesów recyklingu (36), gdzie: mozs $_{4}$ - masa złomu do strzępienia, $\mathrm{f}_{\mathrm{rl}}$ - procentowy udział frakcji metali żelaznych (dane z próby strzępienia), $\mathrm{f}_{\mathrm{r} 2}$ - procentowy udział frakcji metali nieżelaznych (dane $\mathrm{z}$ próby strzępienia), $\mathrm{f}_{\mathrm{r} 3}$ - procentowy udział frakcji tworzywa sztucznego (dane z próby strzępienia).

\section{Zadanie odzysku elementów z silnika}

Z analizy poszczególnych poziomów oddziaływań generowanych podczas odzysku i składowania materiałów 
from this metal. To this end one has to perform a disassembly of the individual engines.

The performed optimization research of the disassembly of the engines with the use of a modeling algorithm presented in this paper have led to a recovery of the following number of components for each individual engine type respectively: $15,27,30$ and 32 pieces. The recovery of such a number of components allowed obtaining:

$11.62 \mathrm{~kg}$ aluminum from the SSM engine,

$32.23 \mathrm{~kg}$ aluminum from the SSP engine,

$24.91 \mathrm{~kg}$ aluminum from the SSL engine,

$32.47 \mathrm{~kg}$ aluminum from the SSN engine.

The mutual relations of the share of the recovered aluminum against the total mass of individual engines have been shown in Fig. 5.

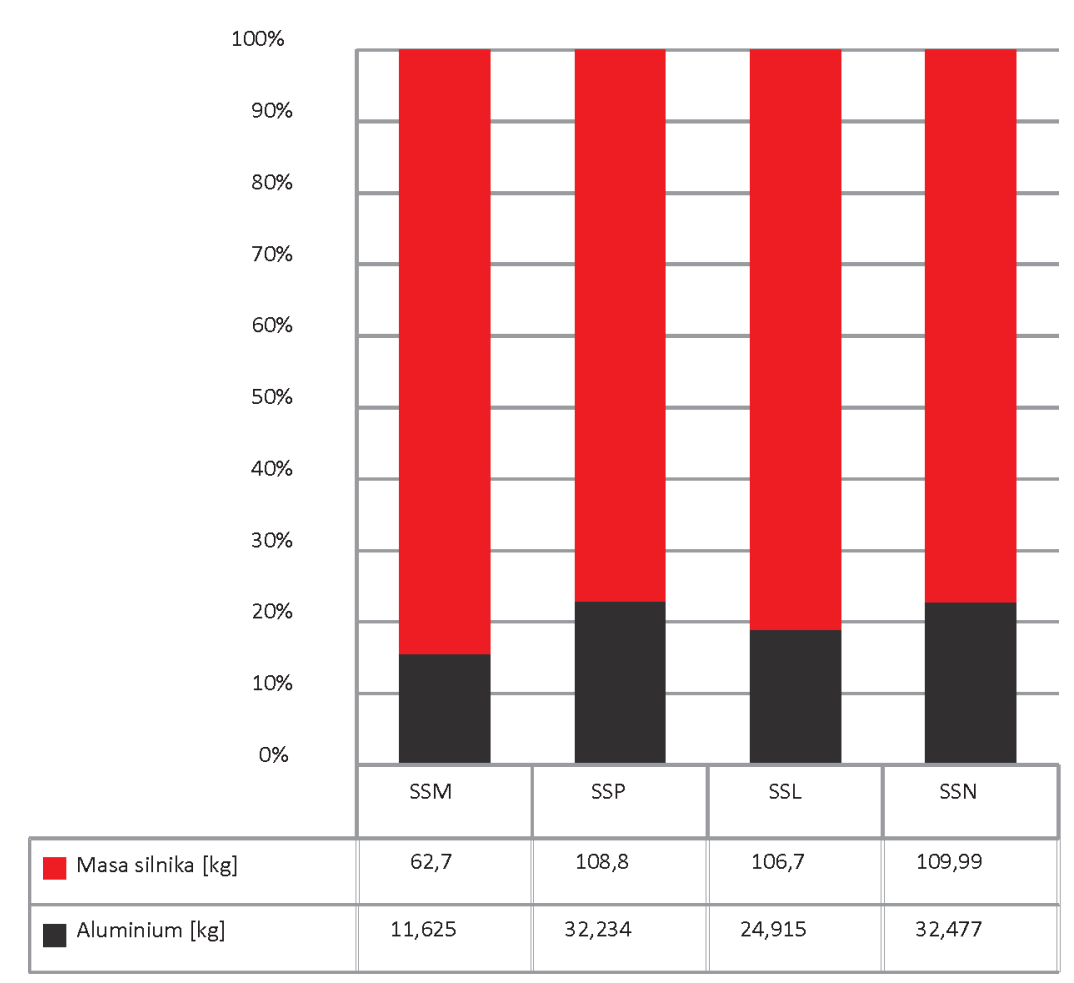

Fig. 5. The proportional part of recovered aluminium to the total mass of the engine Rys. 5. Procentowy udzial odzyskanego aluminium w odniesieniu do całkowitej masy silnika (rys. 4) wynika, że odzysk złomu metali nieżelaznych przynosi większe korzyści niż odzysk złomu metali żelaznych, których masa w konstrukcji analizowanego silnika stanowi ponad 60\% masy całej jednostki. Przy tak dużych korzyściach środowiskowych celowe staje się podjęcie próby optymalizacji odzysku złomu metali nieżelaznych z tego typu silnika. W strukturze złomu metali nieżelaznych dominującym materiałem jest aluminium i jego stopy.

Zadanie polega na przeprowadzeniu odzysku aluminium z silnika SSM, SSP, SSL i SSN. Aluminium będzie pozyskane ze zdemontowanych elementów, które zostały wytworzone $\mathrm{z}$ tego materiału. W tym celu należy przeprowadzić proces demontażu poszczególnych silników.

Przeprowadzone badania optymalizacyjne demontażu wymienionych silników, z wykorzystaniem algorytmu modelowania przedstawionego w niniejszym artykule, doprowadziły do odzyskania następującej liczby elementów odpowiednio dla każdego modelu silnika: 15 , 27, 30 i 32 sztuk. Odzyskanie takiej liczby elementów umożliwiło pozyskanie: $11,62 \mathrm{~kg}$ aluminium z silnika SSM, $32,23 \mathrm{~kg}$ aluminium z silnika SSP, $24,91 \mathrm{~kg}$ aluminium z silnika SSL, $32,47 \mathrm{~kg}$ aluminium $\mathrm{z}$ silnika SSN.

Wzajemne zależności udziału odzyskanego aluminium do całkowitej masy poszczególnych silników przedstawiono na rys. 5.

\section{Wnioski}

Prowadzone badania ekobilansowe obiektów technicznych, jakimi są silniki spalinowe, pokazały, że celowe jest prowadzenie badań nad poprawą ich przyjazności środowiskowej. Ograniczenie ich emisyjności na obecnym etapie nie jest wystarczające, aby zmniejszyć wpływ silników na środowisko.

Na podstawie wyników przeprowadzonej analizy ekobilansowej wymienionych w pracy silników za celowe uznano doskonalenie badań nad procesem demontażu wycofanych z eksploatacji

\section{Conclusions}

The performed environmental research of technological objects such as combustion engines have shown that it is recommended to conduct further research to improve its environment friendliness. Limiting the engines' emission level on the current level is not sufficient to reduce the impact of combustion engines on the environment.

Based on the results of the conducted environmental analysis of the here presented engines the authors think it is desirable to continue the improvement of the research on the disassembly of end of life engines. The process of optimization of the disassembly of end of life engines leads to a growth in the level of recycling and recovery not only silników. Proces optymalizacji demontażu wycofanych z eksploatacji silników prowadzi do wzrostu poziomu recyklingu i odzysku nie tylko dla danej jednostki, ale też prowadzi do wzrostu tych wskaźników w odniesieniu do pojazdów samochodowych, w których zostały wykorzystane jako jednostki napędowe.

Przykładem mogą być uzyskane wyniki z badań optymalizacyjnych i doświadczalnych samochodu wycofanego z eksploatacji, do napędu którego wykorzystano silnik SSP. Badania doświadczalne odzysku elementów i materiałów z samochodu wycofanego z eksploatacji przeprowadzono bez demontażu silnika spalinowego. Badania te pozwoliły na uzyskanie poziomu odzysku z samochodu wycofanego z eksploatacji (POSWE(PC)1) o wysokości 79,96\%, a 
for a given unit but also in relation to the complete vehicles where these engine were fitted.

The example could be the results of optimization related and experimental investigations of an end of life vehicle for which the SSP engine was used. The experimental investigations of the recovery of the components and materials from a vehicle withdrawn from operation were performed without the disassembly of the engine. The investigations enabled a recovery level of an end of life vehicle (POSWE(PC)1) recycling level $79.96 \%$, recycling (PRSWE(PC)1) of 78.23\%. The optimization investigations, however, of the recovery of the components and materials from the vehicle where the process of disassembly was included led to a growth of the analyzed indexes: recovery level (POSWE(PC)1) up to $88.07 \%$ and recycling level (PRSWE(PC)1) up to $86.33 \%$. The results divided into optimization and experimental investigations have been shown in Fig. 6 .

Artykut recenzowany

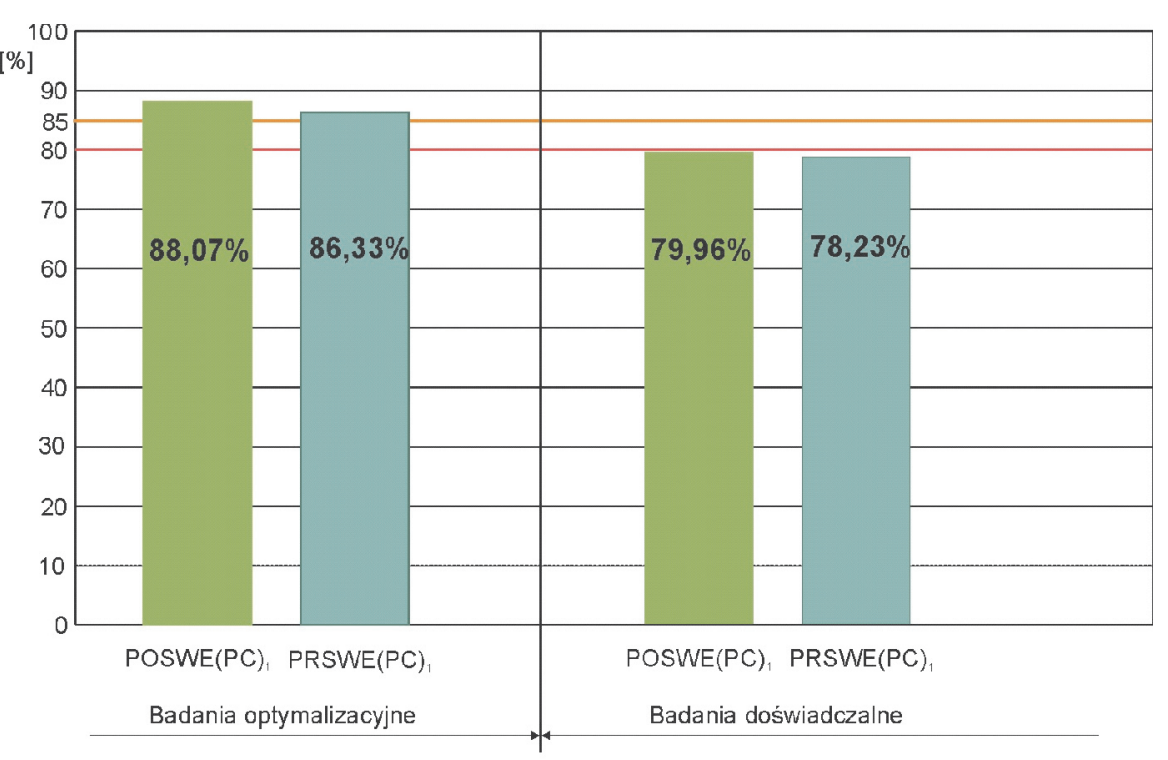

Fig. 6. Values of the level of recovery (PO) and recycling (PR) end of life vehicle SWE(PC)1 Rys. 6. Wartości poziomu odzysku (PO) i recyklingu (PR) samochodu wycofanego z eksploatacji $S W E(P C) 1$

recyklingu (PRSWE(PC)1) - 78,23\%. Natomiast przeprowadzone badania optymalizacyjne odzysku elementów i materiałów z badanego pojazdu samochodowego, w których uwzględniono proces demontażu silnika doprowadziły do wzrostu analizowanych wskaźników: poziomu odzysku (POSWE(PC)1) do 88,07\%, a poziomu recyklingu (PRSWE(PC)1) do $86,33 \%$. Wyniki badań z podziałem na badania optymalizacyjne i doświadczalne przedstawiono na rys. 6 .

\section{Nomenclature/Skróty i oznaczenia}

LCA Life Cycle Assessment/ekologiczna ocena cyklu życia

PO Level of Recovery/poziom odzysku
PR Level of Recycling/poziom recyklingu

SWE End-of-life Vehicle/samochód wycofany z eksploatacji

\section{Bibliography/Literatura}

[1] Kulczycka J.: Ekologiczna ocena cyklu życia (LCA) nową techniką zarządzania środowiskowego. Wydawnictwo Instytutu Gospodarki Surowcami Mineralnymi i Energią PAN, Kraków 2001.

[2] Ustawa o odpadach z dnia 27.04.2001 (Dz. U. Nr 62, poz. 628).

[3] Łebkowski P.: Model planowania demontażu maszyn i urządzeń. Zagadnienia Eksploatacji Maszyn. Tribologia, niezawodność, eksploatyka, diagnostyka, bezpieczeństwo, Polska Akademia Nauk, Komitet Budowy Maszyn, Instytut Technologii Eksploatacji, vol. 37, z. 4 (132), s. 151-162, Radom 2002.

[4] Ambroziak T.: Modelowanie procesów technologicznych w transporcie. Prace Naukowe Politechniki Warszawskiej Transport, z. 40, Oficyna Wydawnicza Politechniki Warszawskiej, Warszawa 1998.
[5] Jarzębińska-Dziegciar A.: Optymalizacja nieliniowych sieci transportowych z wykorzystaniem algorytmów genetycznych. Rozprawa doktorska, Politechnika Warszawska, Wydział Transportu, Warszawa 2004.

[6] Korzan B.: Elementy teorii grafów i sieci. Metody i zastosowania. Wydawnictwa Naukowo-Techniczne, Warszawa 1978.

Norbert Chamier-Gliszczyński, DEng. - assistant professor at the Koszalin University of Technology.

Dr inż. Norbert Chamier-Gliszczyński - adiunkt na Wydziale Mechanicznym Politechniki Koszalińnkiej. e-mail: norbert.chamier-gliszczynski@tu.koszalin.pl

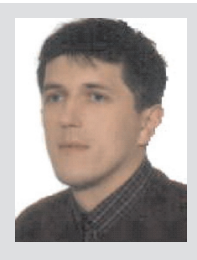

